\title{
Change of growth performance, hematological parameters, and plasma component by hexavalent chromium exposure in starry flounder, Platichthys stellatus
}

\author{
Hye-Dong Ko, Hee-Ju Park and Ju-Chan Kang*
}

\begin{abstract}
The study investigated the changes in growth performance, hematological parameters, plasma components, and stress indicators of juvenile starry flounder, Platichthys stellatus, depending on varying exposure to hexavalent chromium. P. stellatus was exposed to waterborne chromium at 0, 50, 100, 200, and $400 \mathrm{ppb}$ for 4 weeks. The result showed that $\mathrm{Cr}$ exposure resulted in decreased daily length gain (DLG), daily weight gain (DWG), condition factor (CF), and hepatosomatic index (HIS) in P. stellatus. In terms of hematological parameters, red blood cell (RBC) count, hematocrit $(\mathrm{Ht})$, and hemoglobin $(\mathrm{Hb})$ significantly decreased at $400 \mathrm{ppb}$ after 2 weeks. In terms of plasma components, inorganic analysis was unchanged and cholesterol, an organic component, considerably increased at $400 \mathrm{ppb}$ after 4 weeks. Plasma enzyme components including glutamic oxalate transaminase (GOT) and glutamic pyruvate transaminase (GPT) were significantly increased. Stress indicators such as cortisol and glucose were notably increased over $100 \mathrm{ppb}$ after 4 weeks with increasing chromium concentration. The results indicate that exposure to waterborne $\mathrm{Cr}$ induced toxic effects on growth, hematological parameters, plasma components, and stress indicators.
\end{abstract}

Keywords: Starry flounder, Hexavalent chromium, Growth, Hematological parameters, Stress

\section{Introduction}

Fish are one of the most important food resources and are considered as sources of the primary protein worldwide. Ongoing marine pollution increases the concentration of toxic metals in water and negatively affects fish health. These pollutants, which have a negative effect on fish, are released by agriculture, industrial wastewater discharge, raw sewage extraction, chemical waste, and oil spills due to fishing vessels (Velusamy et al. 2014). Waterborne metal exposure affects the physiological and biochemical factors in fish blood and tissues.

Among the three states of chromium including zero-valent chromium, trivalent chromium, and hexavalent chromium, the trivalent state occurs naturally

\footnotetext{
* Correspondence: jckang@pknu.ac.kr

Department of Aquatic Life Medicine, Pukyong National University, Busan, Republic of Korea
}

during weathering, and low-grade denaturation, while the zero-valent and hexavalent chromium are generally produced industrially (Oze et al. 2004a). The chromium concentration in the environment generated by weathering and secondary reactions is a silicate mineral associated with chromate (Oze et al. 2004b). Chromium concentrations in various environments range from 1 to $3000 \mathrm{mg} / \mathrm{kg}$ in soil, 5 to $800 \mu \mathrm{g} / \mathrm{L}$ in seawater, and $0.02 \mu \mathrm{g} / \mathrm{L}$ to $6.0 \mathrm{mg} / \mathrm{L}$ in groundwater (Tchounwou et al. 2012; Jacobs and Testa 2005). Chromium is mainly used to manufacture ferroalloys and other alloys and is a common pollutant found in surface and groundwater; however, high levels of chromium exposure due to natural resources are not commonly observed (Robles-Camacho and Armienta 2000). The main sources of chromium contamination include chrome compounds produced in chemical plants for welding, grinding, and 
polishing of stainless steel, as well as chrome electroplating, dyeing, leather processing, and wood processing for other applications (Kumari et al. 2014; Liu et al. 2011; Vasudevan et al. 2010; Ellis et al. 2002). Trivalent chromium is not only toxic, but also an important element in controlling blood sugar by enhancing insulin action in humans. On the other hand, hexavalent chromium is highly reactive and a strong irritant; it is designated as a carcinogen (Krumschnabel and Nawaz 2004).

Growth performance is a factor reflecting environmental toxicity in fish, and even a small concentration of heavy metals has a negative effect, triggering physiological changes such as growth and metabolism and reducing health and survival rates (Hussain et al. 2010). Hematological parameters are used to effectively monitor the status of fish exposed to various types of toxicity in the aquatic environment (Garcia et al. 2016). The main goal of ecotoxicology in aquatic ecosystems is to assess the toxicity of aquatic organisms and humans (Ribeiro et al. 2006). Hematological parameters such as red blood cell count, hematocrit, and hemoglobin concentration are widely used indicators of fish health status under metal toxicity (Khalid et al. 2016). Hematological indicators, including enzymes, metabolites, nutrients, and inorganic ions, are used to determine cell damage and measure the response to heavy metal exposure (Öner et al. 2008). In addition, blood cortisol levels have been widely used as stress biomarkers in fish exposed to heavy metals (Norris et al. 1999; Mishra and Mohanty 2009).

Starry flounder, $P$. stellatus, is a common flatfish inhabiting the margins of North Pacific and represents one of the most popular fish in Korea currently. Because it is resistant to disease and advantageous to eat at low temperatures, its survival rate is higher than that of the cultured olive flounder, Paralichthys olivaceus (Ding et al. 2010; Kang et al. 2011). Its aquaculture and production are important because of its high demand and marketability (Lee et al. 2003; Song et al. 2014). However, studies investigating chromium toxicity are unavailable. Therefore, the goal of this study was to assess the toxic effects of hexavalent chromium exposure on P. stellatus in terms of growth performance, hematological parameters, plasma components, and stress indicators.

\section{Materials and method}

\section{Experimental fish and conditions}

P. stellatus was obtained from a local farm in Gijang, Korea. The fish acclimated for 2 weeks under laboratory conditions. During the experimental period, feeds were supplied at $2 \%$ of body weight every day and completely changed water every 2 days. Feeds gave the common commercial feed consisting of more than $60 \%$ crude protein used in the fish farm. The seawater used in the experimental is shown in Table 1 and has a temperature of $15 \pm 1.0^{\circ} \mathrm{C}$, dissolved oxygen (DO) $7.3 \pm 0.4$, chemical oxygen demand (COD) $1.15 \pm 0.1$, and $\mathrm{pH} 7.5 \pm 0.5$. After acclimation, 60 fish (body length, $19.2 \pm 0.9 \mathrm{~cm}$, and body weight, $112.5 \pm 15.7 \mathrm{~g}$ ) were randomly selected for the study. The chromium experiments were performed with waterborne chromium, and exposed solutions were prepared using potassium dichromate (Sigma, St. Louis, MO, USA). Exposure to hexavalent chrome was evaluated using 250-L circular tanks on 12 fish per group. The hexavalent chromium concentrations were $0,50,100,200$, and $400 \mu \mathrm{g}$ per liter using potassium dichromate in distilled water. At the end of each period ( 2 to 4 weeks), the fish were anesthetized after $15 \mathrm{mg} / \mathrm{L}$ diluted solution of 3-aminobenzoic acid ethyl ester methanesulfonate which was buffered to $\mathrm{pH} 7.0-7.5$ with sodium carbonate (Sigma Chemical, St. Louis, Mo, Molinero and Gonzalez 1995). To reduce and maintain water pollution, the water tank was completely replaced every 2 days and the same concentration was maintained in each aquarium before and after the change. The total exposure duration was 4 weeks, during which no mortality occurred. Thirty fish were sampled at 2 weeks (total length, $19.6 \pm 0.2 \mathrm{~cm}$; body weight, $118.0 \pm 3.5 \mathrm{~g}$ ) and 4 weeks (total length, $20.1 \pm 0.5 \mathrm{~cm}$; body weight, $123.0 \pm 5.9 \mathrm{~g})$.

\section{Growth performance}

Mortality was not observed during the experimental periods. The weight and length of $P$. stellatus was measured immediately before exposure, at 2 weeks and 4 weeks. Daily length gain (DLG), daily weight gain (DWG), condition factor (CF), and hepatosomatic index (HSI) were calculated as the following methods.

Daily length gains $=($ final length-initial length $) /$ day

Daily weight gains $=($ final weight-initial weight $) /$ day

Condition factor $(\%)=\left[\right.$ weight $(\mathrm{g}) /$ length $\left.^{3}(\mathrm{~cm})\right] \times 100$

Hepatosomatic index $=($ liver weight $/$ total fish weight $) \times 100$

Table 1 The chemical composition of seawater and experimental conditions used in the experiments

\begin{tabular}{ll}
\hline Composition & Value \\
\hline Temperature $\left({ }^{\circ} \mathrm{C}\right)$ & $15.0 \pm 1.0$ \\
$\mathrm{pH}$ & $7.5 \pm 0.5$ \\
Salinity $(\%)$ & $32.3 \pm 0.5$ \\
Dissolved oxygen $(\mathrm{mg} / \mathrm{L})$ & $7.3 \pm 0.4$ \\
Chemical oxygen demand $(\mathrm{mg} / \mathrm{L})$ & $1.15 \pm 0.1$ \\
Ammonia $(\mu \mathrm{g} / \mathrm{L})$ & $11.3 \pm 0.9$ \\
Nitrite $(\mu \mathrm{g} / \mathrm{L})$ & $1.6 \pm 0.3$ \\
Nitrate $(\mu \mathrm{g} / \mathrm{L})$ & $10.31 \pm 1.1$ \\
\hline
\end{tabular}




\section{Hematological parameters}

Blood samples were collected in $30-40 \mathrm{~s}$ through the caudal vein of fish using a 1-ml disposable heparinized syringe. Blood samples were stored at $4{ }^{\circ} \mathrm{C}$ until blood parameters were thoroughly studied. Red blood cell (RBC) count, hematocrit (Ht), and hemoglobin $(\mathrm{Hb})$ concentration were analyzed immediately. After dilution with Hendrick's diluting solution, total number of RBC was counted using optical microscope equipped with hemocytometer (Improved Neubauer, Germany). $\mathrm{Hb}$ concentration was analyzed by the Cyan-methemoglobin technique (Asan Pharm. Co., Ltd.). Also, Ht value was analyzed by the microhematocrit centrifugation technique using a capillary tube and a microcentrifuge (Hawksley \& Sons, Ltd.). Blood samples are centrifuged at $3000 \mathrm{~g}$ for $5 \mathrm{~min}$ at $4{ }^{\circ} \mathrm{C}$ to separate the plasma from the blood sample.

\section{Plasma component}

In inorganic analysis, calcium and magnesium were analyzed by the o-cresolphthalein-complexon technique and xylidyl blue technique (Asan Pharm. Co., Ltd.). In organic analysis, total protein was determined by GOD/ POD method and burette method (Asan Pharm. Co., Ltd.), and total cholesterol was analyzed by quinone method (Asan Pharm. Co., Ltd.). In enzyme activity analysis, glutamic oxalate transaminase (GOT) and glutamic pyruvate transaminase (GPT) were determined by Kind-King technique (Asan Pharm. Co., Ltd.).

\section{Stress indicator}

Plasma cortisol concentrations were measured by monoclonal antibody enzyme-linked immunosorbent assay (ELISA) quantitation kit (Enzo Life Sciences, Inc., Farmingdale, NY, USA). Plasma glucose was determined by GOD/POD method and burette method (Asan Pharm. Co., Ltd.).

\section{Results}

\section{Growth performance}

The growth rate and hepatosomatic index of $P$. stellatus are shown in Fig. 1. The daily length gain was considerably decreased at concentrations exceeding $400 \mathrm{ppb}$ at 2 and 4 weeks, and the daily weight gain was significantly decreased over $400 \mathrm{ppb}$ at 2 weeks, and over $200 \mathrm{ppb}$ at 4 weeks. A notable reduction in condition was observed at $400 \mathrm{ppb}$ after 2 and 4 weeks. Hepatosomatic index was significantly decreased at $400 \mathrm{ppb}$ after 2 weeks and over $200 \mathrm{ppb}$ after 4 weeks.

\section{Hematological parameters}

The RBC count, hematocrit values, and hemoglobin concentration of $P$. stellatus exposed to different levels

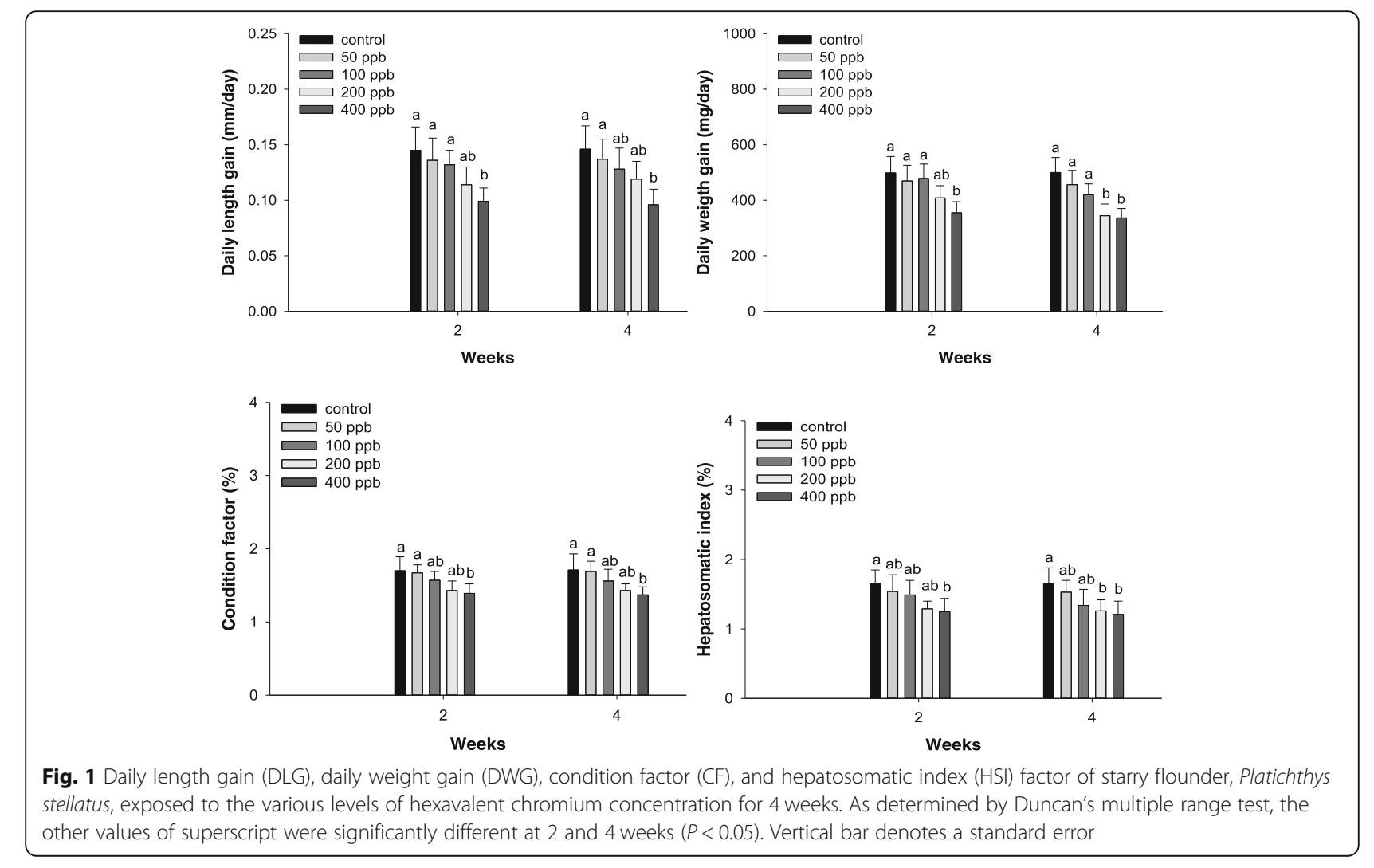


of hexavalent chromium are listed in Fig. 2. The RBC count was considerably decreased over $400 \mathrm{ppb}$ after 2 weeks. The hematocrit value and hemoglobin were significantly decreased over $400 \mathrm{ppb}$ after 2 weeks and over $200 \mathrm{ppb}$ after 4 weeks.

\section{Plasma components}

The plasma inorganic components of $P$. stellatus are presented in Table 2. Calcium and magnesium levels among the plasma inorganic components remained unchanged. The plasma organic components of P. stellatus are listed in Table 2 and were analyzed for total cholesterol and protein levels. The cholesterol level showed a notable increase over $400 \mathrm{ppb}$ after 4 weeks. By contrast, there was no change in total protein concentration.

The plasma enzyme components of P. stellatus are listed in Fig. 3 and were analyzed for GOT and GPT. In terms of enzyme components, the GOT level was significantly increased over $400 \mathrm{ppb}$ after 2 and 4 weeks, and the GPT level was significantly increased at concentrations greater than $400 \mathrm{ppb}$ after 4 weeks.

\section{Stress indicators}

The plasma cortisol and glucose concentration in P. stellatus exposed to hexavalent chromium are presented in Fig. 3. Plasma cortisol was considerably elevated at levels greater than $200 \mathrm{ppb}$ after 2 weeks and at levels exceeding $100 \mathrm{ppb}$ after 4 weeks. In addition, glucose was considerably elevated over $200 \mathrm{ppb}$ after 2 weeks and over $100 \mathrm{ppb}$ after 4 weeks of $\mathrm{Cr}$ exposure.

\section{Discussion}

Hexavalent chromium exposures increase the accumulation of heavy metals in tissues, resulting in multiple derangements such as abnormal behavior, decreased growth, and increased mortality (Farag et al. 2006).

Growth inhibition is also a prominent effect of metal accumulation following chronic exposure (Zebral et al. 2018). Sherwood et al. (2000) reported that growth reduction under metal contamination increased the energy costs due to increased metabolism. Exposure to hexavalent chromium significantly inhibited the growth of $P$. stellatus, and the conditional factors were significantly reduced by chromium exposure.

Hematological parameters such as RBC count, Ht value, and $\mathrm{Hb}$ profile are sensitive indicators in the evaluation of fish metabolism under metal stress (Vinodhini and Narayanan 2009). Further, hematological parameters are widely used in toxicological investigations and environmental monitoring as a promising indicator of physiological changes in fish under stress (Kavitha et al. 2010). In the present study, hexavalent chromium exposure induced a significant reduction in $\mathrm{RBC}$ count, $\mathrm{Ht}$ value, and $\mathrm{Hb}$ concentration of $P$.
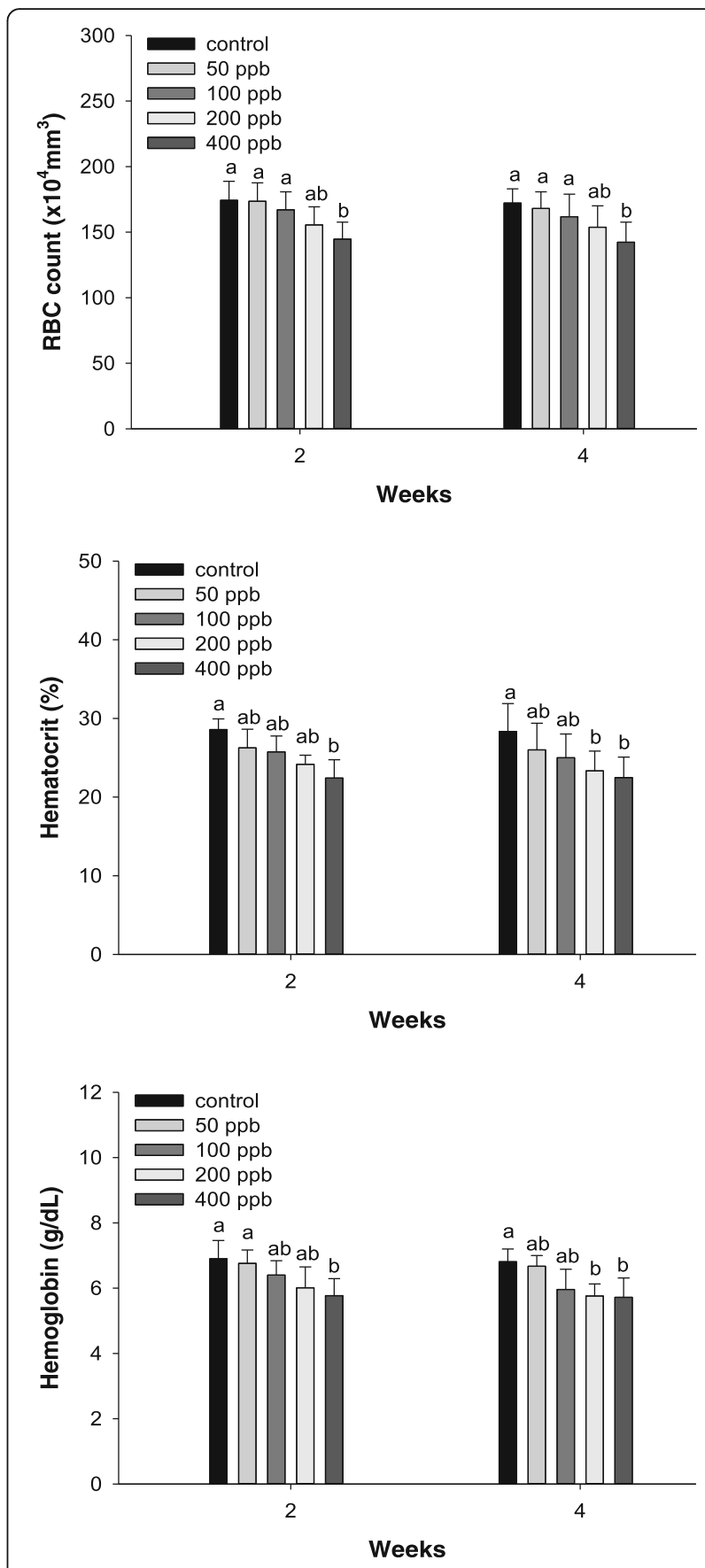

Fig. 2 Changes of RBC count, hematocrit, and hemoglobin in starry flounder, Platichthys stellatus, exposed to the different hexavalent chromium concentration for 4 weeks. Values are mean \pm SE. As determined by Duncan's multiple range test, the other values of superscript were significantly different at 2 and 4 weeks $(P<0.05)$

stellatus, which may be attributed to toxic effects such as hemophilia, red cell shrinkage, osmoregulation, and gill injury (Saravanan et al. 2011). Gill and Epple (1993) reported that metals act directly on hematopoietic stem cells in the kidney and spleen, with abnormal membrane permeability and mechanical failure, and induce anemia 
Table 2 Changes of plasma inorganic and organic substances in starry flounder, Platichthys stellatus, exposed to the different hexavalent chromium concentration for 4 weeks

\begin{tabular}{lllllll}
\hline Parameters & $\begin{array}{l}\text { Period } \\
(\text { week })\end{array}$ & \multicolumn{5}{l}{ Chromium concentration $(\mu \mathrm{g} / \mathrm{L})$} \\
\cline { 3 - 7 } & & 0 & 50 & 100 & 200 & 400 \\
\hline Calcium $(\mathrm{mg} / \mathrm{dL})$ & 2 & $18.80 \pm 1.59^{\mathrm{a}}$ & $19.01 \pm 1.90^{\mathrm{a}}$ & $19.39 \pm 1.15^{\mathrm{a}}$ & $20.34 \pm 1.57^{\mathrm{a}}$ & $18.12 \pm 1.63^{\mathrm{a}}$ \\
& 4 & $19.21 \pm 1.33^{\mathrm{a}}$ & $19.33 \pm 1.27^{\mathrm{a}}$ & $20.24 \pm 1.46^{\mathrm{a}}$ & $18.28 \pm 2.05^{\mathrm{a}}$ & $18.61 \pm 1.37^{\mathrm{a}}$ \\
Magnesium (mg/dL) & 2 & $2.98 \pm 0.44^{\mathrm{a}}$ & $3.25 \pm 0.55^{\mathrm{a}}$ & $3.11 \pm 0.30^{\mathrm{a}}$ & $3.60 \pm 0.27^{\mathrm{a}}$ & $3.68 \pm 0.66^{\mathrm{a}}$ \\
& 4 & $3.43 \pm 0.58^{\mathrm{a}}$ & $3.58 \pm 0.62^{\mathrm{a}}$ & $3.42 \pm 0.60^{\mathrm{a}}$ & $3.24 \pm 0.54^{\mathrm{a}}$ & $3.60 \pm 0.61^{\mathrm{a}}$ \\
cholesterol (mg/dL) & 2 & $210.5 \pm 21.2^{\mathrm{a}}$ & $217.4 \pm 12.2^{\mathrm{a}}$ & $218.6 \pm 11.5^{\mathrm{a}}$ & $239.1 \pm 21.2^{\mathrm{ab}}$ & $250.1 \pm 19.7^{\mathrm{ab}}$ \\
& 4 & $215.0 \pm 18.8^{\mathrm{a}}$ & $225.5 \pm 13.3^{\mathrm{a}}$ & $231.5 \pm 25.8^{\mathrm{ab}}$ & $248.2 \pm 16.4^{\mathrm{ab}}$ & $264.6 \pm 31.5^{\mathrm{b}}$ \\
Total protein (g/dL) & 2 & $10.21 \pm 1.21^{\mathrm{a}}$ & $9.43 \pm 1.14^{\mathrm{a}}$ & $9.68 \pm 0.72^{\mathrm{a}}$ & $10.07 \pm 0.66^{\mathrm{a}}$ & $10.32 \pm 0.59^{\mathrm{a}}$ \\
& 4 & $10.30 \pm 0.44^{\mathrm{a}}$ & $10.21 \pm 0.91^{\mathrm{a}}$ & $10.03 \pm 1.19^{\mathrm{a}}$ & $9.54 \pm 0.32^{\mathrm{a}}$ & $9.93 \pm 0.38^{\mathrm{a}}$ \\
\hline
\end{tabular}

Values are mean \pm SE. As determined by Duncan's multiple range test, Different small letters indicate significantly different value at 2 and 4 weeks $(P<0.05)$

by decreasing the oxygen supply due to red blood cell concentration and decreased hemoglobin (Kumar and Banerjee 2016). Hepatosomatic index is used as an important indicator of health status in aquatic animals manifesting the toxic effects of metal exposure (Datta et al. 2007; Bolger and Connolly 1989). Vosyliené and Jankaite reported (Vosyliené and Jankaité 2006) that changes in hepatosomatic index were observed depending on the metal concentration and exposure time. The hepatosomatic index decreased, and limited hepatic dysfunction was observed following toxic exposure. Exposure to hexavalent chromium has a significant negative impact on the growth and hepatosomatic index of $P$. stellatus.

In this experiment, the inorganic components of plasma calcium and magnesium of $P$. stellatus were not significantly changed by hexavalent chromium exposure. Plasma calcium levels are maintained at a constant level by bone metabolism and mediate various enzymatic action functions. Their role in calcium metabolism depends on heavy metal classification (Suzuki et al. 2004). The calcium concentration did not show any significant change in this experiment. In this experiment, plasma calcium may be reduced by brief exposures to
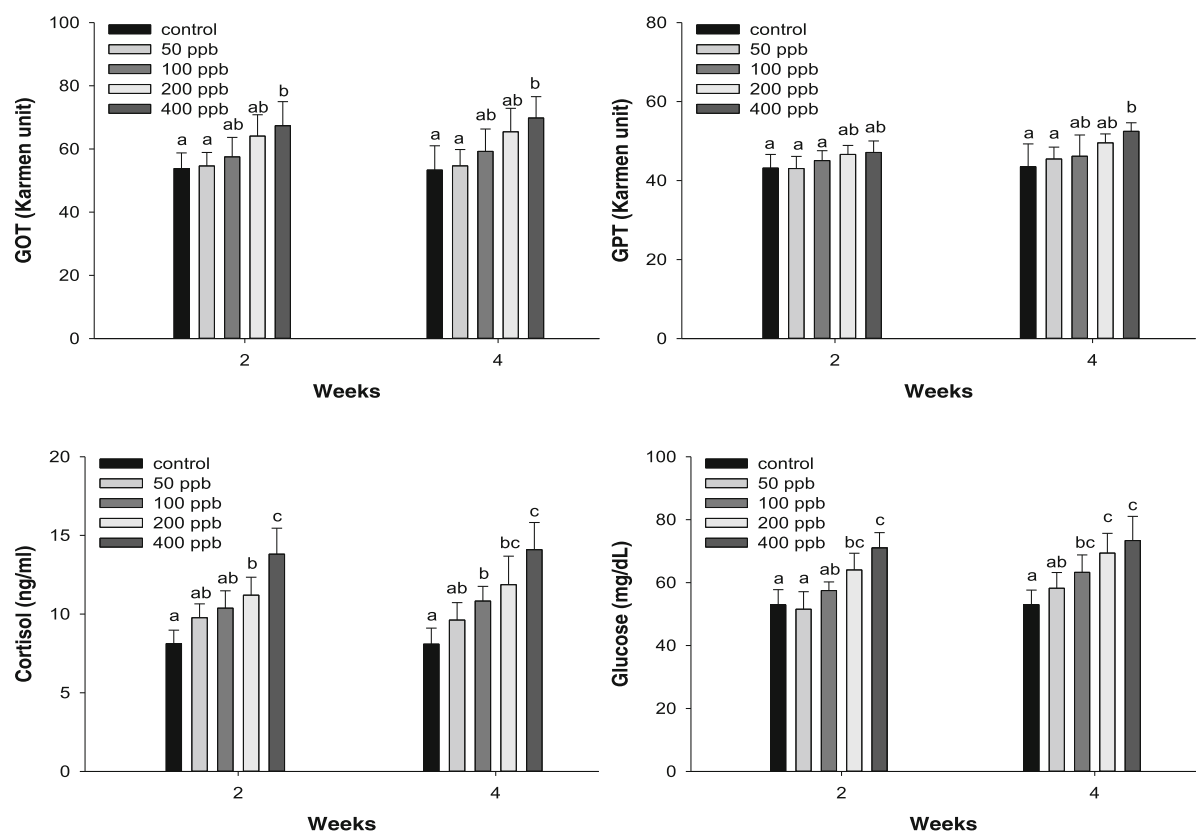

Fig. 3 Changes of GOT, GPT, plasma cortisol, and glucose in starry flounder, Platichthys stellatus, exposed to the various levels of hexavalent chromium concentration for 4 weeks. As determined by Duncan's multiple range test, the other values of superscript were significantly different at 2 and 4 weeks $(P<0.05)$ 
heavy metals and apparently restored by homeostasis (Pratap et al. 1989; Suzuki et al. 2004). Magnesium exhibits a mechanism similar to calcium.

Protein metabolism is one of the important parameters underlying the biological mechanisms of toxicity (Saravanan et al. 2011). Proteins are an immediate source of energy during stress in many organisms, and the reduction in plasma protein levels may be due to impaired protein synthesis or metabolism (Ramesh et al. 2014). Total protein, a plasma organic substance, was decreased slightly but not significantly. The reduced protein levels have often been reported in acute experiments, without fatal outcomes in this experiment (Vutukuru 2005, Gopal et al. 1997). Total cholesterol was significantly increased only at high concentrations by week 4 . Cholesterol is the precursor of all steroid hormones and is an essential structural component of the cell membrane (Yang and Chen 2003). Changes in the blood parameters of fish can be attributed to metallic stress, and plasma parameters such as glucose, total protein, and total cholesterol are indicators of heavy metal toxicity. (Firat and Kargin 2010).

The enzymes GOT and GPT in P. stellatus were significantly increased following exposure to the highest levels of hexavalent chromium. Transaminases such as GOT and GPT represent useful biomarkers for biomonitoring of chemical pollutants in aquatic organisms, in which altered levels of transaminases indicate compensatory mechanisms against impaired metabolism (Ramesh et al. 2014; Sathya et al. 2012; Reddy and Venugopal 1991). Since the liver is rich in GOT and GPT, a large concentration of enzyme is released into the blood following damage, and the increase in enzyme activity is used as an indicator of water pollution (Vaglio and Landriscina 1999). As a result, the plasma components of $P$. stellatus were significantly altered by hexavalent chromium exposure.

In this study, glucose and cortisol in P. stellatus was significantly increased by exposure to hexavalent chromium. Plasma glucose is a reliable indicator of multiple stress factors in fish, including heavy metals, and is commonly increased by carbohydrate metabolism (CiCiK and ENGiN 2005). The increase in glucose level is attributed to the breakdown of proteins and high-density lipids, resulting in the release of carbohydrates, and decreased lipid and protein levels, following metal toxicity (Kumar and Banerjee 2016). Plasma cortisol levels are widely used in the primary response to stressors such as metals and insecticides; cortisol and other corticosteroid hormones maintain homeostasis under toxicity (Frrat et al. 2011). Pratap and Wendelaar Bonga (1990) reported frequent association between increased plasma cortisol and glucose in fish following exposure to water pollutants or other stressors, and the relationship was mostly causal.

\section{Conclusion}

In conclusion, this study demonstrates that waterborne chromium exposure significantly affects the health of experimental starry flounders. These results also suggest that exposure of starry flounders to elevated doses of waterborne chromium may reduce the growth performance and decrease various hematological parameters. However, the plasma levels of GOT and GPT were enhanced, and the stress response mediated by cortisol and glucose was confirmed by the changes in stress indicators. These results indicate that the toxic effects of waterborne exposure to hexavalent chromium altered the growth, hematological parameters, and the concentration of plasma components, and stress indicators.

\section{Abbreviations \\ Cr: Chromium; GOT: Glutamate-oxalacetate transaminase; GPT: Glutamate- pyruvate transaminase; Hb: Hemoglobin; Ht: Hematocrit; RBC: Red blood cell}

\section{Acknowledgements}

This research was supported by the Basic Science Research Program through the National Research Foundation of Korea (NRF) funded by the Ministry of Education (2017R1D1A3B03030464).

Funding

This study was funded by the National Institute of Fisheries Science under Technology Development Program for Fisheries Research.

Availability of data and materials

All datasets generated and/or analyzed during the current study are available from the corresponding author on reasonable request.

\section{Authors' contributions}

$\mathrm{HJ}$ carried out the environmental toxicity studies and manuscript writing. HD participated in the design of the study and data analysis. JC participated in its design and coordination and helped to draft the manuscript. All authors read and approved the final manuscript.

\section{Ethics approval and consent to participate}

All experimental animals used in this study were maintained under a protocol approved by the Institutional Animal Care and Use Committee of the Pukyong National University.

Consent for publication

Not applicable.

Competing interests

The authors declare that they have no competing interests.

\section{Publisher's Note}

Springer Nature remains neutral with regard to jurisdictional claims in published maps and institutional affiliations.

Received: 10 December 2018 Accepted: 22 April 2019

Published online: 21 May 2019

\section{References}

Bolger T, Connolly PL. The selection of suitable indices for the measurement and analysis of fish condition. J Fish Biol. 1989;34(2):171-82.

CiCiK B, ENGiN K. The effects of cadmium on levels of glucose in serum and glycogen reserves in the liver and muscle tissues of Cyprinus carpio (L., 1758). Turk J Vet Anim Sci. 2005;29(1):113-7.

Datta S, Saha DR, Ghosh D, Majumdar T, Bhattacharya S, Mazumder S. Sub-lethal concentration of arsenic interferes with the proliferation of hepatocytes and induces in vivo apoptosis in Clarias batrachus L. Comp Biochem Physiol Part C: Toxicol \& Pharmacol. 2007;145(3):339-49. 
Ding L, Zhang L, Wang J, Ma J, Meng X, Duan P, et al. Effect of dietary lipid level on the growth performance, feed utilization, body composition and blood chemistry of juvenile starry flounder (Platichthys stellatus). Aquac Res. 2010;41(10):1470-8.

Ellis AS, Johnson TM, Bullen TD. Chromium isotopes and the fate of hexavalent chromium in the environment. Science. 2002;295(5562):2060-2.

Farag AM, May T, Marty GD, Easton M, Harper DD, Little EE, Cleveland L. The effect of chronic chromium exposure on the health of Chinook salmon (Oncorhynchus tshawytscha). Aquat Toxicol. 2006;76(3-4):246-57.

Fırat Ö, Cogun HY, Yüzereroğlu TA, Gök G, Firat Ö, Kargin F, Kötemen Y. A comparative study on the effects of a pesticide (cypermethrin) and two metals (copper, lead) to serum biochemistry of Nile tilapia, Oreochromis niloticus. Fish Physiol Biochem. 2011;37(3):657-66.

Firat Ö, Kargin F. Individual and combined effects of heavy metals on serum biochemistry of Nile tilapia Oreochromis niloticus. Arch Environ Contam Toxicol. 2010;58(1):151-7.

Garcia GG, Miguel EJL, Gabriel MAL, Mingala CN. The corollary effect of heavy metal accumulation in freshwater ponds on the hematological profile of Nile Tilapia (Oreochromis niloticus). Environ Exp Biol. 2016;14:69-73.

Gill TS, Epple A. Stress-related changes in the hematological profile of the American eel (Anguilla rostrata). Ecotoxicol Environ Saf. 1993;25(2):227-35.

Gopal V, Parvathy S, Balasubramanian PR. Effect of heavy metals on the blood protein biochemistry of the fish Cyprinus carpio and its use as a bio-indicator of pollution stress. Environ Monit Assess. 1997:48(2):117-24.

Hussain SM, Javed M, Asghar S, Hussain M, Abdullah S, Raza SA, Javid A. Studies on growth performance of metals mixture stressed Cirrhina mrigala in earthen ponds. Pak J Agri Sci. 2010;47(3):263-70.

Jacobs JA, Testa SM. Overview of chromium (VI) in the environment: background and history. Chromium (VI) handbook; 2005. p. 1-21.

Kang JH, Kim YK, Park JY, An CM, Nam MM, Byun SG, et al. Microsatellite analysis as a tool for discriminating an interfamily hybrid between olive flounder and starry flounder. Genet Mol Res. 2011;10(4):2786-94.

Kavitha C, Malarvizhi A, Kumaran SS, Ramesh M. Toxicological effects of arsenate exposure on hematological, biochemical and liver transaminases activity in an Indian major carp, Catla catla. Food Chem Toxicol. 2010; 48(10):2848-54.

Khalid MV, Qureshi NA, Mubarik MS, Bukhari SA. Heavy metals (copper, chromium and cadmium) induced oxidative stress biomarkers on haematological parameters of Labeo rohita. Oxid Commun. 2016;39(1):163-76.

Krumschnabel G, Nawaz M. Acute toxicity of hexavalent chromium in isolated teleost hepatocytes. Aquat Toxicol. 2004;70(2):159-67.

Kumar R, Banerjee TK. Arsenic induced hematological and biochemical responses in nutritionally important catfish Clarias batrachus (L.). Toxicol Rep. 2016;3:148-52.

Kumari K, Khare A, Dange S. The applicability of oxidative stress biomarkers in assessing chromium induced toxicity in the fish Labeo rohita. Biomed Res Int. 2014;2014:782493.

Lee SM, Lee JH, Kim KD. Effect of dietary essential fatty acids on growth, body composition and blood chemistry of juvenile starry flounder (Platichthys stellatus). Aquaculture. 2003;225(1-4):269-81.

Liu YX, Yuan DX, Yan JM, Li QL, Ouyang T. Electrochemical removal of chromium from aqueous solutions using electrodes of stainless steel nets coated with single wall carbon nanotubes. J Hazard Mater. 2011;186(1):473-80.

Mishra AK, Mohanty B. Effect of hexavalent chromium exposure on the pituitaryinterrenal axis of a teleost, Channa punctatus (Bloch). Chemosphere. 2009: 76(7):982-8.

Molinero A, Gonzalez J. Comparative effects of MS 222 and 2-phenoxyethanol on gilthead sea bream (Sparus aurata L.) during confinement. Comp Biochem Physiol A Physiol. 1995;111(3):405-14.

Norris DO, Donahue S, Dores RM, Lee JK, Maldonado TA, Ruth T, Woodling JD. Impaired adrenocortical response to stress by brown trout, Salmo trutta, living in metal-contaminated waters of the Eagle River, Colorado. Gen Comp Endocrinol. 1999;113(1):1-8

Öner M, Atli G, Canli M. Changes in serum biochemical parameters of freshwater fish Oreochromis niloticus following prolonged metal (ag, $\mathrm{cd}, \mathrm{Cr}, \mathrm{Cu}, \mathrm{Zn}$ ) exposures. Environ Toxicol Chem. 2008;27(2):360-6.

Oze C, Fendorf S, Bird DK, Coleman RG. Chromium geochemistry in serpentinized ultramafic rocks and serpentine soils from the Franciscan complex of California. Am J Sci. 2004a;304(1):67-101.

Oze C, Fendorf S, Bird DK, Coleman RG. Chromium geochemistry of serpentine soils. Int Geol Rev. 2004b;46(2):97-126.
Pratap HB, Fu H, Lock RAC, Bonga SW. Effect of waterborne and dietary cadmium on plasma ions of the teleostOreochromis mossambicus in relation to water calcium levels. Arch Environ Contam Toxicol. 1989;18(4):568-75.

Pratap HB, Wendelaar Bonga SE. Effects of water-borne cadmium on plasma cortisol and glucose in the cichlid fish Oreochromis mossambicus; 1990.

Ramesh M, Sankaran M, Veera-Gowtham V, Poopal RK. Hematological, biochemical and enzymological responses in an Indian major carp Labeo rohita induced by sublethal concentration of waterborne selenite exposure. Chem Biol Interact. 2014;207:67-73.

Reddy SLN, Venugopal NBRK. In vivo effects of cadmium chloride on certain aspects of protein metabolism in tissues of a freshwater field crabBarytelphusa guerini. Bull Environ Contam Toxicol. 1991;46(4):583-90.

Ribeiro CO, Neto FF, Mela M, Silva PH, Randi MAF, Rabitto IS, et al. Hematological findings in neotropical fish Hoplias malabaricus exposed to subchronic and dietary doses of methylmercury, inorganic lead, and tributyltin chloride. Environ Res. 2006;101(1):74-80.

Robles-Camacho J, Armienta MA. Natural chromium contamination of groundwater at Leon Valley, Mexico. J Geochem Explor. 2000;68(3):167-81.

Saravanan M, Kumar KP, Ramesh M. Haematological and biochemical responses of freshwater teleost fish Cyprinus carpio (Actinopterygii: Cypriniformes) during acute and chronic sublethal exposure to lindane. Pestic Biochem Physiol. 2011;100(3):206-11.

Sathya V, Ramesh M, Poopal RK, Dinesh B. Acute and sublethal effects in an Indian major carp Cirrhinus mrigala exposed to silver nitrate: Gill $\mathrm{Na}+/ \mathrm{K}$ +-ATPase, plasma electrolytes and biochemical alterations. Fish Shellfish Immunol. 2012:32(5):862-8.

Sherwood GD, Rasmussen JB, Rowan DJ, Brodeur J, Hontela A. Bioenergetic costs of heavy metal exposure in yellow perch (Perca flavescens): in situ estimates with a radiotracer (137Cs) technique. Can J Fish Aquat Sci. 2000;57(2):441-50.

Song Z, Li H, Wang J, Li P, Sun Y, Zhang L. Effects of fishmeal replacement with soy protein hydrolysates on growth performance, blood biochemistry, gastrointestinal digestion and muscle composition of juvenile starry flounder (Platichthys stellatus). Aquaculture. 2014;426:96-104.

Suzuki N, Yamamoto M, Watanabe K, Kambegawa A, Hattori A. Both mercury and cadmium directly influence calcium homeostasis resulting from the suppression of scale bone cells: the scale is a good model for the evaluation of heavy metals in bone metabolism. J Bone Miner Metab. 2004;22(5):439-46.

Tchounwou PB, Yedjou CG, Patlolla AK, Sutton DJ. Heavy metal toxicity and the environment. In: Molecular, clinical and environmental toxicology. Basel: Springer; 2012. p. 133-64

Vaglio A, Landriscina C. Changes in liver enzyme activity in the TeleostSparus auratain response to cadmium intoxication. Ecotoxicol Environ Saf. 1999; 43(1):111-6.

Vasudevan S, Lakshmi J, Vanathi R. Electrochemical coagulation for chromium removal: process optimization, kinetics, isotherms and sludge characterization. CLEAN-Soil, Air, Water. 2010;38(1):9-16.

Velusamy A, Kumar PS, Ram A, Chinnadurai S. Bioaccumulation of heavy metals in commercially important marine fishes from Mumbai Harbor, India. Mar Pollut Bull. 2014;81(1):218-24.

Vinodhini R, Narayanan M. The impact of toxic heavy metals on the hematological parameters in common carp (Cyprinus carpio L.). Iranian J Environ Health Sci Eng (IJEHSE). 2009;6:1.

Vosylienè $\mathrm{MZ}$, Jankaite A. Effect of heavy metal model mixture on rainbow trout biological parameters. Ekologija. 2006;4:12-7.

Vutukuru SS. Acute effects of hexavalent chromium on survival, oxygen consumption, hematological parameters and some biochemical profiles of the Indian major carp, Labeo rohita. Int J Environ Res Public Health. 2005;2(3): $456-62$.

Yang JL, Chen HC. Effects of gallium on common carp (Cyprinus carpio): acute test, serum biochemistry, and erythrocyte morphology. Chemosphere. 2003; 53(8):877-82.

Zebral YD, Anni ISA, Afonso SB, Abril SIM, Klein RD, Bianchini A. Effects of lifetime exposure to waterborne copper on the somatotropic axis of the viviparous fish Poecilia vivipara. Chemosphere. 2018;203:410-7. 